\title{
Essential Preventive Automobile Maintenance during a Pandemic
}

\author{
Hrvoje GLAVAŠ, Mirko KARAKAŠIĆ*, Milan KLJAJIN, Eleonora DESNICA
}

\begin{abstract}
Passenger cars require different types of periodic maintenance. The most common and well-known procedure is the replacement of oil and filters, the so-called basic service. At the time of a pandemic, there is a need for social distance, reduced interaction between people and avoidance of all possible contamination of personal belongings. Oil and filter changes can be planned and optimized in advance but the replacement interval should not be exceeded for a long period of time. Regular replacement is essential to maintain reliability and operation lifetime of vehicles. Due to the unknown duration of the pandemic, the car owner can approach the maintenance procedure in a do it yourself (DIY) manner. Necessary spare parts can be ordered online and received by a delivery service without a human contact. The paper provides an overview of two-form practical implementation of basic maintenance that includes the replacement of lubricants and filters. The first maintenance form requires a skillful certified technician and the second form, as an interim service, can be carried out by an everyday user with a certain level of technical education who will independently and periodically monitor the car condition.
\end{abstract}

Keywords car; filters; maintenance; oil; pandemic; service

\section{INTRODUCTION}

The time of the pandemic imposes the need for a social distance, reduced interaction between people and avoidance of possible contamination of personal belongings. A car owned by almost every other person in the EU is a possible solution to maintain a social distance in traffic. All internal combustion (IC) engine vehicles require mandatory basic periodic maintenance, which includes oil and filter changes. The need for carrying out maintenance is best seen in Fig. 1, which shows the consequences of thermodynamic conversion in the engine, [1].

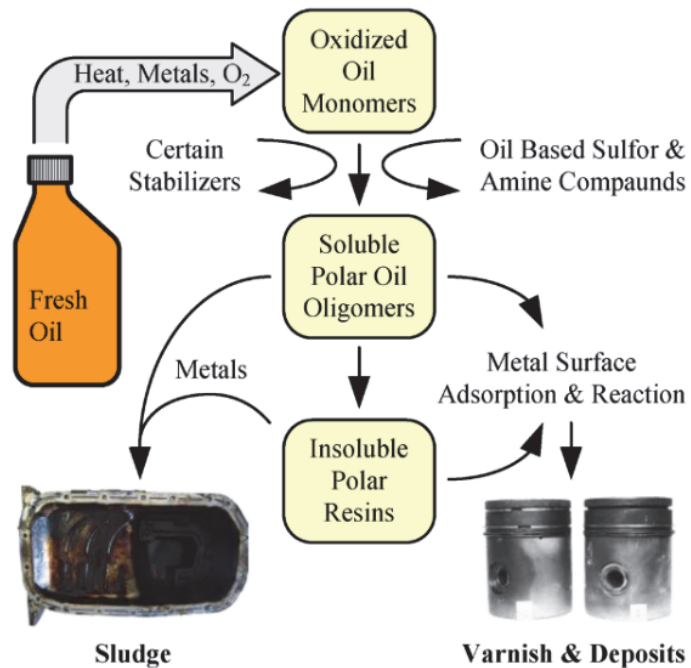

Figure 1 Mechanisms of lubricant degradation motivating the use of antioxidant additives [1]

In the process of the fuel transformation, the car transfers $33 \%$ of the thermal energy to the environment through the exhaust system. The other $67 \%$ raises the internal energy of the IC motor [2]. The vehicle energy balance, which has, over the decades, progressed slowly but has not changed significantly, is best shown in Fig. 2.

The oil temperature in some places of the cylinder reaches $270{ }^{\circ} \mathrm{C}$ [3]. The blow-by gases and sludge particles produced by combustion go into oil leading to degradation of oil that lubricates the walls. Mixing oil with the residue gradually contributes to reducing the mixture quality. This is a basic problem in the car operation. If the car is rarely used during a pandemic or covers a small number of kilometers, basic car maintenance is still an annual obligation. In addition to the oil thermodynamic stress, mineral oils undergo biological degradation of their properties [4]. Contamination and growth of microorganisms in lubricating oils and coolants is a wellknown problem to the lubrication engineer [5].

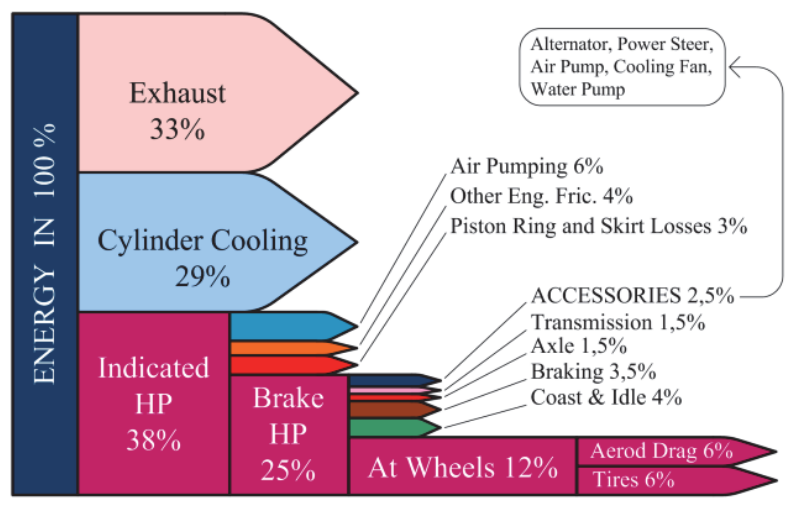

Figure 2 Energy balance of cars with IC motor

The aim of this paper is to provide an overview of twoform practical implementation of basic service on the example of Hyundai i20 vehicles. A vehicle travels an average of $14500 \mathrm{~km}$ a year and consumes 919 liters of fuel.

The first example describes a service procedure that requires technical knowledge of engine operation, knowledge of materials and service procedures to prevent thread destruction by applying excessive force or releasing filters in vehicle operation. Another example analyzes a real situation of everyday users with a certain level of technical education and awareness of the maintenance importance, so-called do-it-yourself (DIY) [6]. In the EU, it is estimated that $10-15 \%$ of all oil changes are carried out by DIY amateurs [7]. California General Statistics indicate that $20 \%$ of oil changes are done in a DIY fashion [8]. 
The personal experiences of the authors, as well as the professional literature, clearly indicate that vehicles will not experience catastrophic failure if the service interval is exceeded (especially for vehicles that make a low number of kilometers per year), but such an approach can lead to excessive wear of engine parts.

\section{BASIC CAR MAINTENANCE}

Basic car maintenance is a complex process that involves inspecting all vehicle systems and replacing consumables and fluids. Aware of the rise of mechatronics [9] in cars, an in-service analysis is limited to a basic predictive maintenance procedure. The emphasis is placed on engine oils that take on multiple functions in the operation of IC motors, air filters that reduce the wear of precision-engineered mechanical assemblies, and passenger cabin filters in charge of maintaining a healthy passenger environment.

\subsection{Automobile Motor Oil}

The basic task of engine oil is to lubricate engine parts, cool pistons, clean and seal. Motor oils in modern vehicles are mostly synthetic oils.

Engine oil viscosity is the most significant feature of engine oil and was classified by SAE J300, Society of Automotive Engineers into six winter (W) grades, and five mono grades. For example, in oil mark 5W40, the first number (5) refers to the viscosity grades (VG) at low temperatures ( $\mathrm{W}$ stands for winter), whereas the second number (40) refers to the VG at high temperatures. A viscosity index (VI) is an empirical number indicating the change in oil viscosity with respect to the increased temperature [10]. By different additives in engine oils, consumption reduction of $2,7 \%$ to $5,8 \%$ and viscosity can be achieved (Fig. 3).

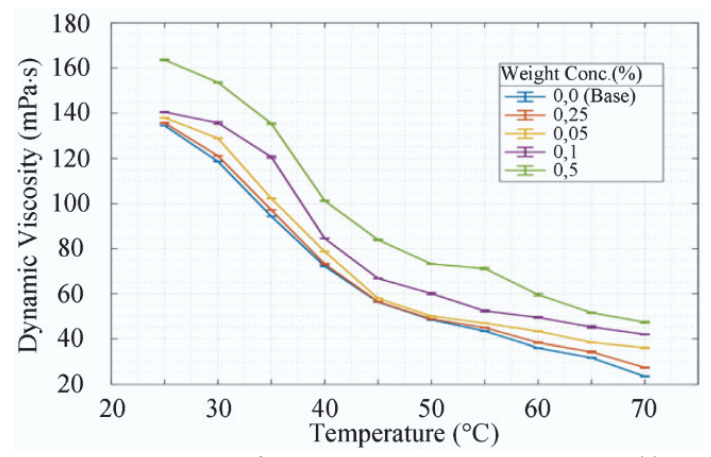

Figure 3 Variation of dynamic viscosity with temperature [11]

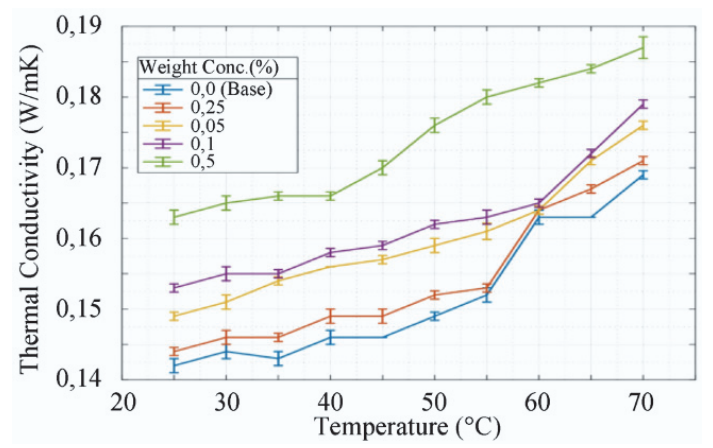

Figure 4 Variation of thermal conductivity with temperature [11]
In addition to viscosity, additives improve the thermal conductivity, which is important in new vehicles because oil cools engine pistons. The influence of additives on thermal conductivity is shown in Fig. 4.

Engine lubricant problems are related to the entry of fuel combustion products in crankcase and lubricant oxidative decomposition at high temperatures in the presence of various metals and materials in the system [10], by wear particle and water contamination. Fig. 5 shows the relative degradation for different oil temperatures in a graphical form where an oil degradation rate of 1,5 indicates a degradation rate that is $50 \%$ greater than a degradation rate of 1,0 [12].

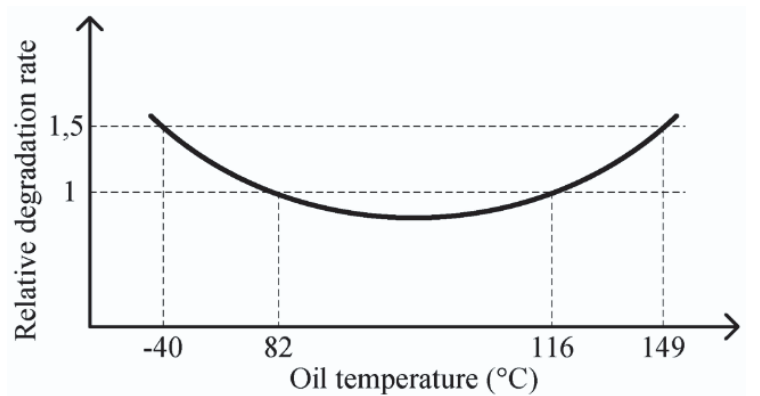

Figure 5 Relation between a relative oil degradation rate and oil temperature $\left({ }^{\circ} \mathrm{C}\right)[12]$

The oil condition can be monitored in real time because it is the only way to determine the optimal moment for replacement [12].

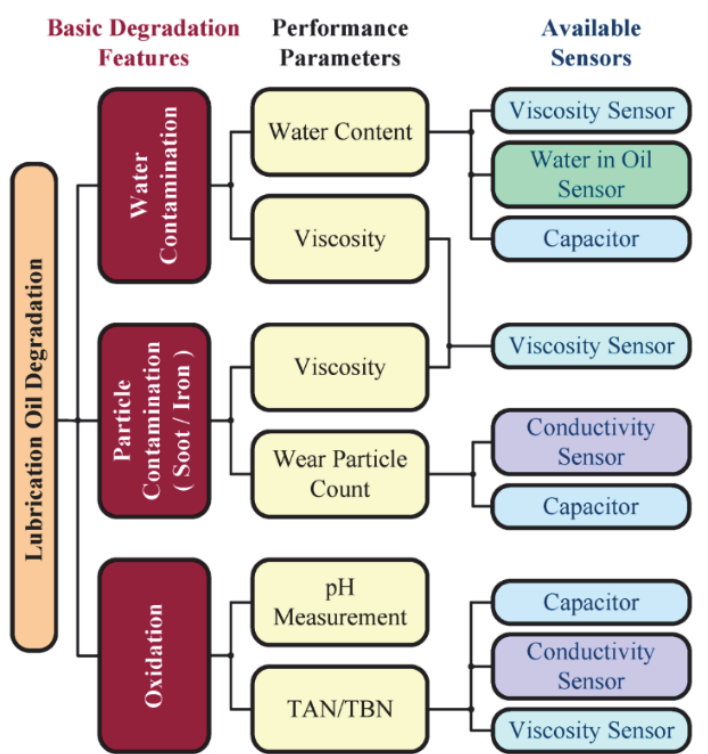

Figure 6 Features that affect lubrication oil degradation [13]

The oil service life depends on a lot of parameters but most often on short-trip driving, road dust, high-mileage engine, diesel engines, alcohol-based fuels, hot running conditions and heavy loads. The relationship between the basic degradation features, performance parameters and available oil condition sensors is shown in Fig. 6 [13].

In order to reduce the consequences of oil degradation, various additives are added to the oil base, which improves its properties as illustrated in Fig. 7. 


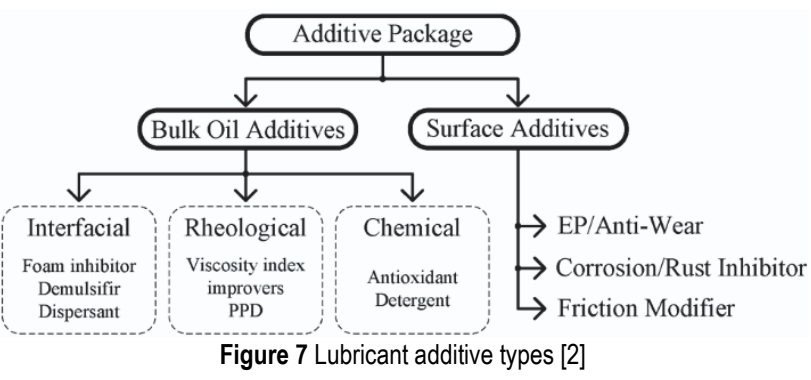

Investigation of the influence of individual additives on the improvement of oil properties is presented in [14]. The percentage of individual additives is shown in Fig. 8.

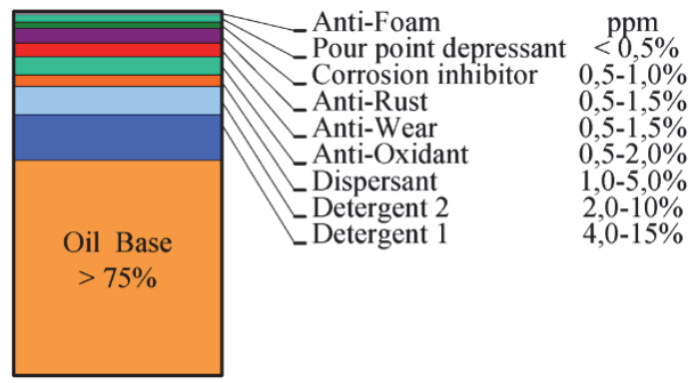

Figure 8 Proportion of additives in engine oil [15]

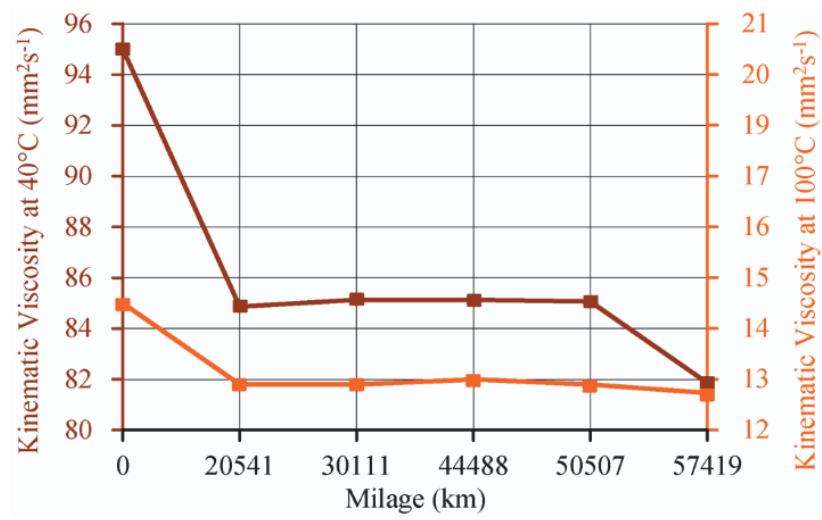

Figure 9 Results of kinematic viscosity at $100^{\circ} \mathrm{C}$ and $40^{\circ} \mathrm{C}[18]$

The vehicle manufacturer prescribes the specifications for the optimal choice of vehicle oil. Information can be found in the vehicle booklet and often on the oil filler cap itself. Replacing higher viscosity oils $10 \mathrm{~W} 40$ with lower viscosity oils $5 \mathrm{~W} 30$ can reduce fuel consumption by $1,6 \%$ to $4,5 \%$ [16]. When replacing, oil gradation possible deviation from what the manufacturer has written should be taken into consideration. The study [17] showed deviations of the characteristics from the declared gradation from $5 \%$ to $25 \%$ (differences of 5 up to $25 \%$ between oil producers' declarations and the laboratory tests results were found). The example of the study conducted on buses [16] shows that oil producers declare larger intervals that were not supported by the conducted tests. On the example of commercial vehicles that have declared change intervals of $40000 \mathrm{~km}$, the research shows that changes should be carried out earlier [18]. The use of expensive motor oil has demonstrated a significant increase in the number of wear particles upon exceeding the suggested motor oil change interval $(40000 \mathrm{~km})$ by approximately $42 \%$. This pinpoints to deficient friction conditions among moving parts of the engine, i.e. increased engine wear. Fig. 9 shows the change in oil viscosity after $44488 \mathrm{~km}$ [18].

The oil change interval is prescribed by oil and car manufacturers. Most manufacturers today keep service intervals in the range of 20000 to $30000 \mathrm{~km}$, and the prediction of future service intervals, according to [19], is up to $50000 \mathrm{~km}$. The vehicle booklet [20], where a practical example is made, indicates a replacement interval after $30000 \mathrm{~km}$ or 12 months. A special reference was made to maintenance in difficult conditions when the replacement interval is after $15000 \mathrm{~km}$ or every 12 months. Although difficult conditions are not explicitly stated, they involve city driving and short distances. The parameters that affect the correction of the replacement interval are stated in [21]. The increase in the replacement interval is due to the need to reduce maintenance costs and ecological footprint of an oil change. The historical increase in the service interval can be seen in Fig. 10 [22].

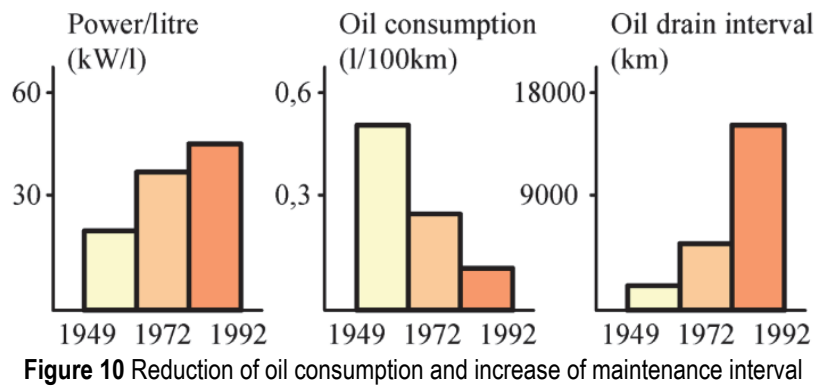

[22]

The optimum oil drain period was found to be $9000 \mathrm{~km}$ for the petrol engine tested in the paper [23]. The reason for this is the decomposition of the additive observed in some oils before $15000 \mathrm{~km}$ [24]. The conclusion of paper [25] states that synthetic oils can operate $11000-13000 \mathrm{~km}$ in 534 - 686 days, semisynthetic oil can operate $7385 \mathrm{~km}$ in 636 days and mineral oil can operate $8200 \mathrm{~km}$ with the condition of $40 \mathrm{~km} /$ day or $5723 \mathrm{~km}$ in 410 days. A practical example of the optimal oil change interval in passenger cars is from Japan - the lubricating oil for gasoline engines of passenger cars is usually exchanged for fresh oil after running a distance in the range from 3000 to $10000 \mathrm{~km}$ [26].

\subsection{Car Oil Filters}

The task of an oil filter is to reduce particle contamination. Today, two basic designs of oil filters are in use. The most common filters are with their own housing, so-called spin-on oil filters (Fig. 11a). Due to environmental reasons, newer vehicles only use a filter cartridge (Fig. 11b) with the housing as an integral part of the engine.

Filter replacement is done by removing used tools (special wrenches or universal tools) [27]. Filter installation is carried out by tightening the prescribed torque, which is in practice usually done manually. Oil must be filtered because severe engine wear is caused by particles in the range of 8 to $60 \mu \mathrm{m}$ [19]. To compare, particle is filtered by masks at $0,007 \mu \mathrm{m}$, corona virus at $0,1 \mu \mathrm{m}$, cigarette smoke from $0,1 \mu \mathrm{m}$ to $1 \mu \mathrm{m}$, bacteria from 3 to $5 \mu \mathrm{m}$, red blood cell from 5 to $7 \mu \mathrm{m}$, talcum powder at $10 \mu \mathrm{m}$, white blood cell at $20 \mu \mathrm{m}$, fine floor dust 
at $40 \mu \mathrm{m}$ and human hair at $80 \mu \mathrm{m}$. The human eye can see particles up to $40 \mu \mathrm{m}$. Fig. 12 shows the abrasion amounts for individual particle sizes found in oil.
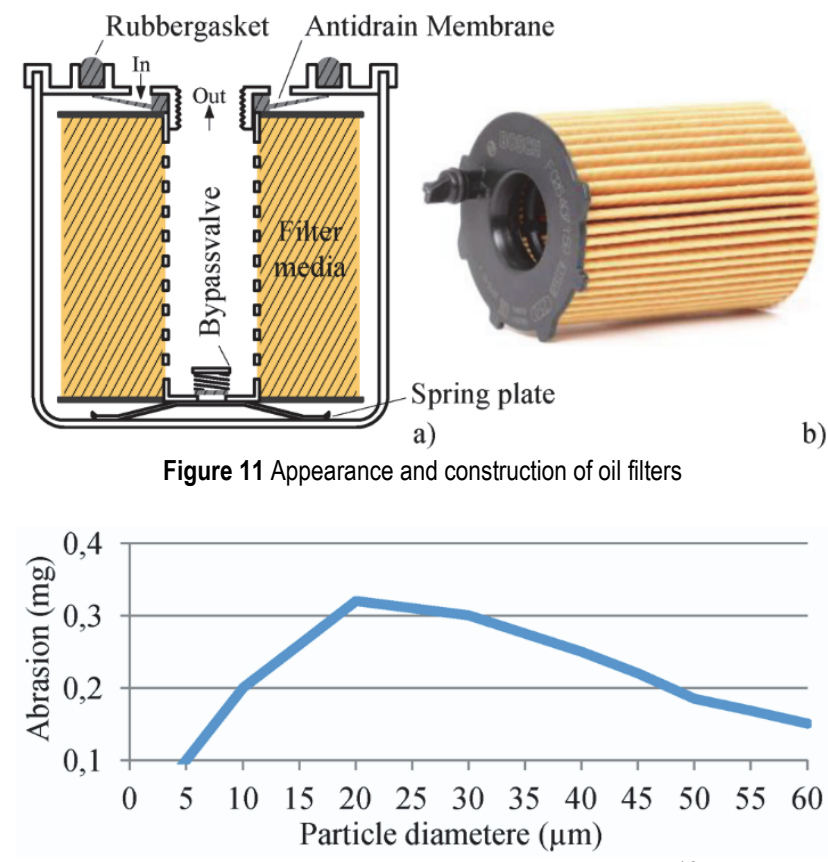

Figure 12 Particle diameter in oil and abrasion level [19]

The materials used for filtration [28] are polyester and glass composite filter material (Fig. 13a), polyester nonwoven filter material, cottonwood pulp filter paper and glass fiber filter paper (Fig. 13b).

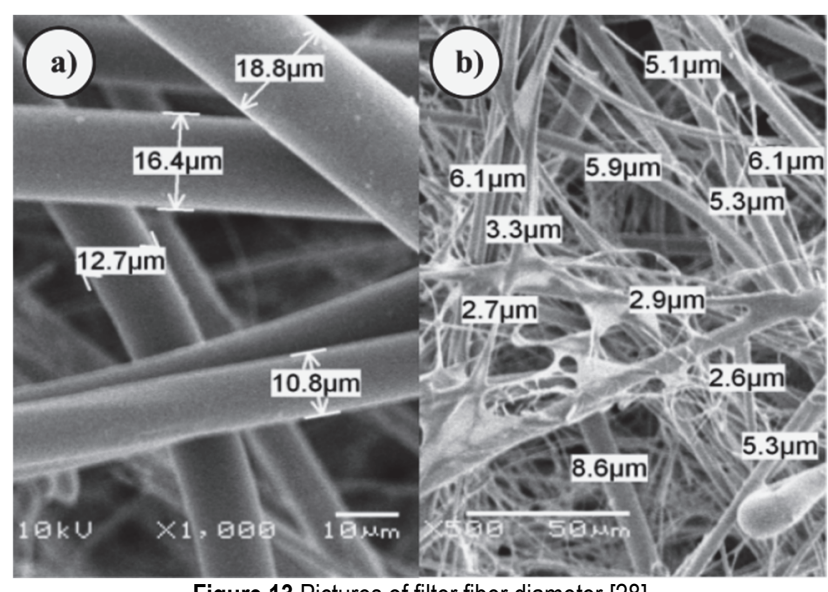

Figure 13 Pictures of filter fiber diameter [28]

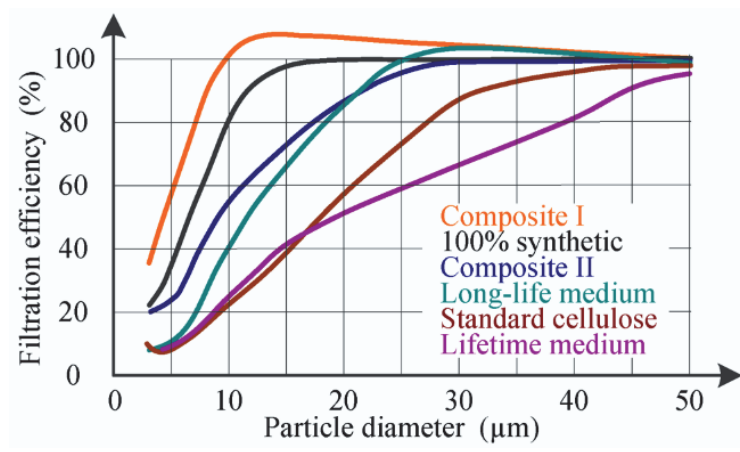

Figure 14 Filtration efficiencies of different filter media [19]

The material the filter is made of is extremely important because its effectiveness reduces the number of particles in oil. Fig. 14 shows the filtration efficiency depending on the material [19].

During operation, the filter becomes clogged and filtration material ages. Aging of filter media in cars with gasoline engines, according to [19], who conducted an experiment on 175 tested vehicles, on average starts at 28000 kilometers and ends at $41000 \mathrm{~km}$. The international standard that covers the area of oil filters is ISO 4548.

\subsection{Air Intake and Cabin Air Filters}

The air necessary for the fuel combustion process contains dust particles, which come mainly from the solid crust of the earth, which is $80 \%$ silica. Silica particles are heavier than structural engine materials, which is particularly important with piston rings and cylinder sleeves since these are directly affected by the presence of small amounts of contaminants in the air intake [29]. Therefore, quality air filtration using an air filter is essential for engine life.

On European roads, estimates indicate that the filter absorbs 50 to 75 grams of dust per 10000 kilometers traveled, based on [19] data. Traditional cellulose air filter media for engines has $99,9 \%$ filtration efficiency for particles above 2 - $5 \mu \mathrm{m}$. Dust particles above $1 \mu \mathrm{m}$ have the highest influence on engine wear. Filter media with nanofiber additions provide greater filtration efficiency of dust grains below $5 \mu \mathrm{m}$. Data [30] state that filter material selection for engine air filter is a problem because manufacturers mainly provide structure parameters like pore size, air permeability and thickness. Filter testing is performed in accordance with ISO 5011:2014 Inlet air cleaning equipment for internal combustion engines and compressors. Testing is performed with dust the composition of which is shown in Fig. 15. The particle size of the test dust and the composition are defined by ISO 12103-1:2016 Road vehicles-Test contaminants for filter evaluation.

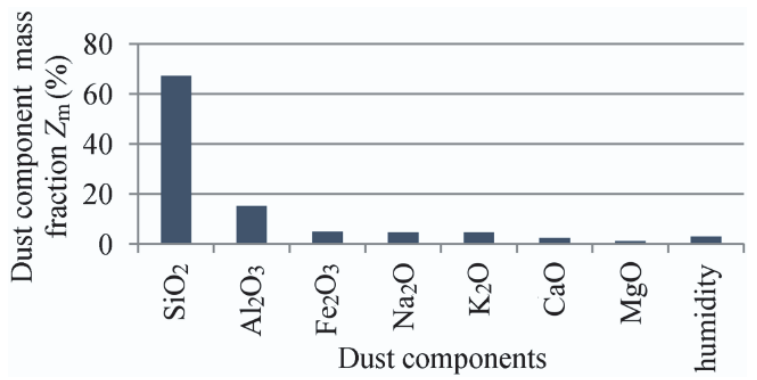

Figure 15 PTC-D test dust used for testing: chemical composition [31]

The representation of individual particles in air filters is shown in Fig. 16 and their appearance in Fig. 17.

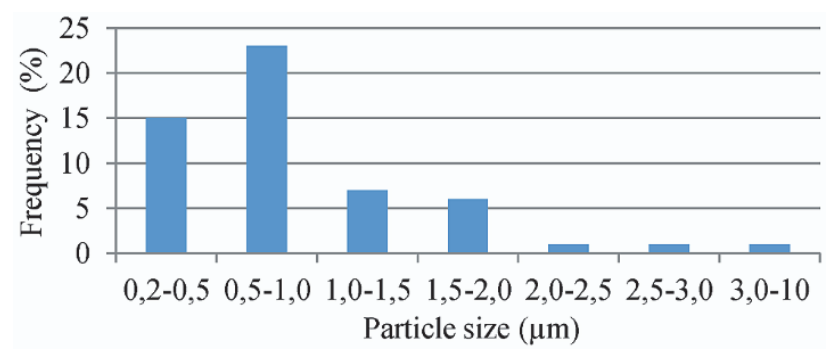

Figure 16 Distribution of particles size collected from car air filters [32] 


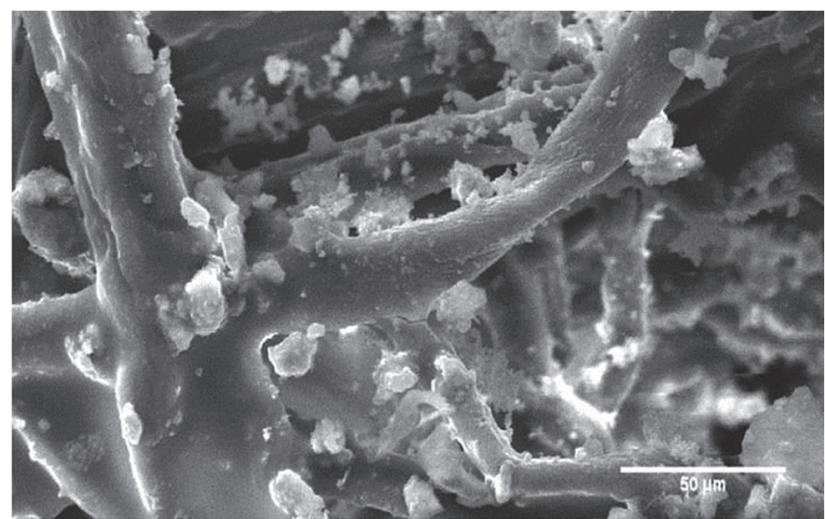

Figure 17 Photomicrographs of particles in car air filters [32]

Glass fibers (Fig. 18) are the basis for the production of modern filters $[32,33]$. The quality factor has proven to be affected by the fiber composition. When the mass percentage was lower than $40 \%$, the quality factor could have used the finer nanofiber. When the mass percentage reached $50 \%$, the fiber nanofiber diameter barely affected the quality factor. When the mass percentage was $70 \%$, the coarser nanofiber outperforms the finer fiber. In order to achieve a higher quality factor, nanofibers are to be effectively separated by the coarse fibers.

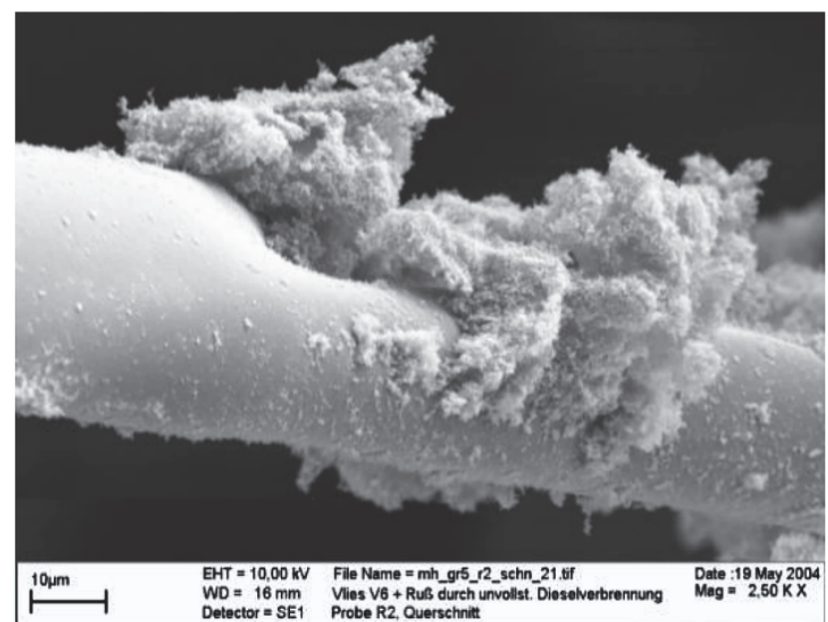

Figure 18 SEM image of partly agglomerated soot particles trapped on a polyester fiber [34]

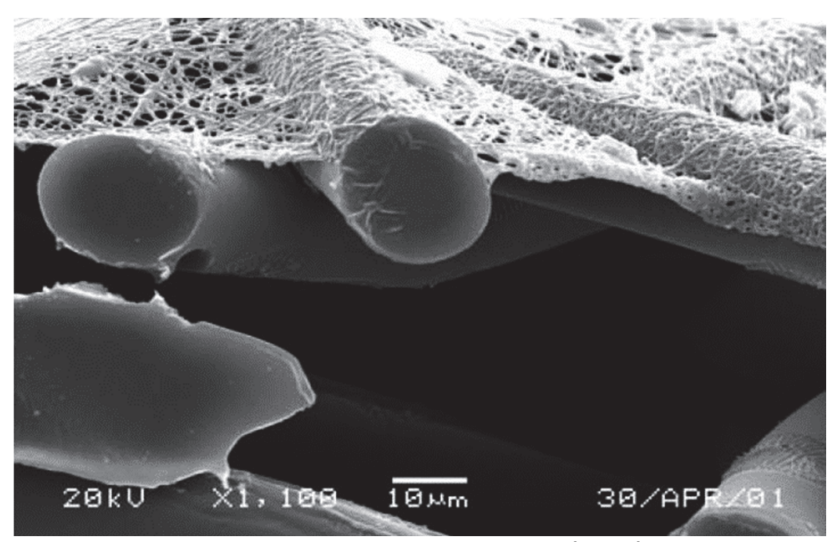

Figure 19 Photomicrograph showing a cross-section of nanofibers electro spun onto a polyester spun bond substrate [36]

Efficiencies in particular can be greatly increased by adding a nanofiber layer on a carrier paper [34]. Very small particles, which normally pass through the big pores of the filter medium (Fig. 18) are filtered by interception and diffusion on the nanofibers. According to [35], a nanofiber layer on a fibrous substrate clearly improved the filtration efficiency of the substrate (Fig. 19). Even the lowest coating weight, $0,02 \mathrm{~g} / \mathrm{m}^{2}$, had a clear effect on efficiency. A coating weight of $0,50 \mathrm{~g} / \mathrm{m}^{2}$ removes approximately $90 \%$ or more aerosol particles regardless of the substrate material. Thicker nanofiber layers are advisable to be protected with a cover layer. Despite the practice, the air filter should not be propelled by an air compressor; rather, it should be replaced because a jet of pressurized air can damage the filter material (Fig. 20).

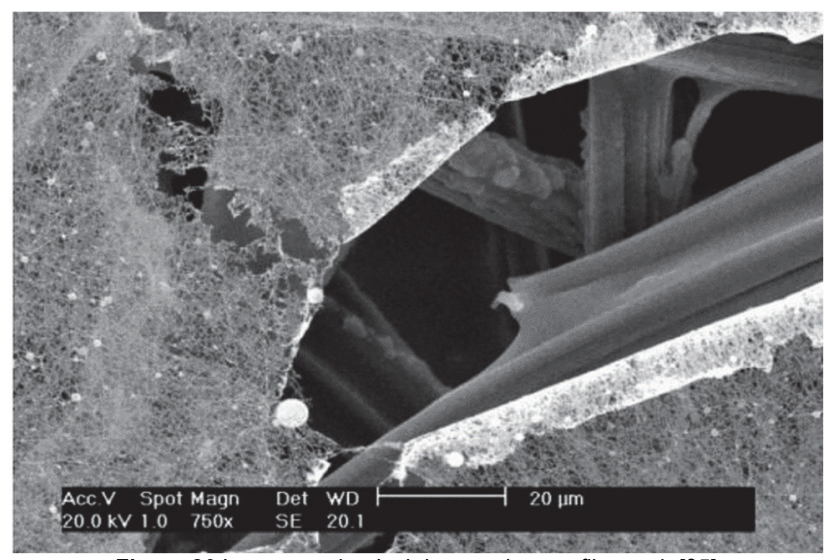

Figure 20 Larger mechanical damage in nanofiber web [35]

The cab filter is often neglected during servicing. The main function of this filter is to stop allergens [37]. Untimely replacement can be a problem because pathogenic organisms develop on it over time [38]. A passenger's health is crucial so a considerable attention is paid to testing cabin filters [39].

\section{BASIC CAR SERVICE IN PRACTICE}

On the example of a 2014 Hyundai i20 1,2; $63 \mathrm{~kW}$ passenger car with a G4LA petrol engine, two approaches to basic vehicle service are shown. They are carried out every 15000 to $30000 \mathrm{~km}$ or once a year. Fig. 21 shows a drive machine with individual parts: cylinder block, oil pump, ladder frame, oil filter, oil pan, and oil drain plug [40].

Prior to oil replacement, the engine must be warmed up to change the oil viscosity in order to accelerate its leakage when the oil drain plug is released. In doing so, it is necessary to loosen the oil filler plug in order to achieve a uniform flow. After the oil leaks, it is necessary to return the oil drain plug with the obligatory change of the aluminum gasket to prevent new oil from leaking. The oil drain plug tightens from 34,3 to $44,1 \mathrm{~N} \cdot \mathrm{m}$. This is followed by the replacement of the filter, which contains about $2 \mathrm{dl}$ of old oil. When unscrewing, it is necessary to pay attention to the reception of the oil contained in the connecting elements and the filter itself. It is also necessary to check that no filter seal is left on the engine block. On the new filter, it is necessary to oil the seal and carefully mount it so that there is no jump on the thread. Hyundai recommends tightening torque from 11,8 to $15,7 \mathrm{~N} \cdot \mathrm{m}$. It is recommended to fill the filter with oil if possible as this reduces the stress on the machine during a start-up. 


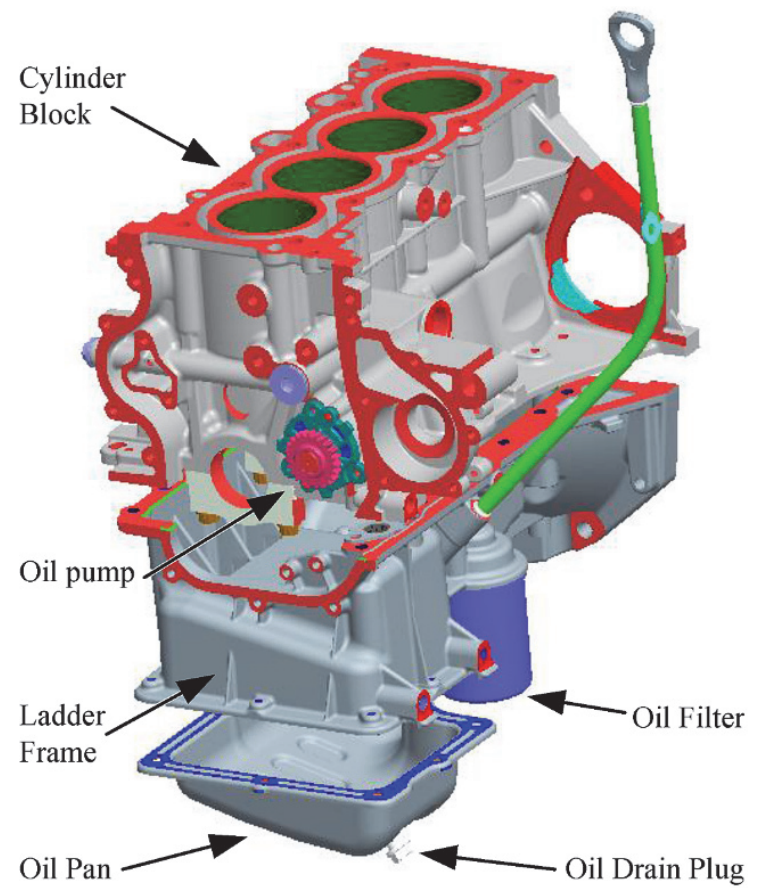

Figure 21 Hyundai i20 Kappa (K) Engine [40]

The engine must be filled with oil recommended in the vehicle booklet. $5 \mathrm{~W} 40$ grade oil was used. It is by no means recommended to fill using the volume indicated in 3,6 1 booklet because there is residual oil in the engine. On average, when replacing, the engine holds 3,2 liters of oil; add 3 liters, start the engine, check for oil leaks, and after turning off the engine, add more oil so that the volume indicator is in the middle. This is followed by the replacement of the engine air filter and passenger compartment filter, which completes the basic service.

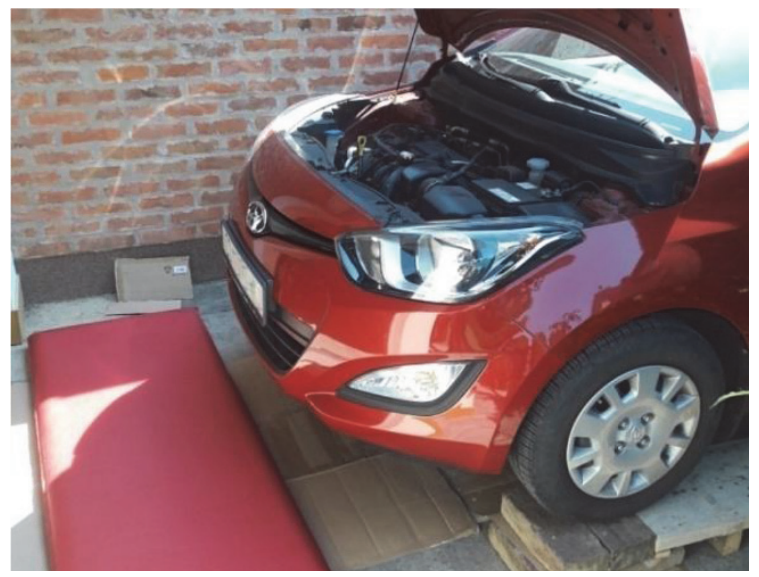

Figure 22 Vehicle on the ramp

The practical implementation of basic vehicle service, in accordance with the manufacturer's recommendations, begins with lifting the vehicle or driving it on the ramp to gain access to the oil drain plug and filter. In Fig. 22, the vehicle tied to the ramp received additional $16 \mathrm{~cm}$ required for key manipulation. If a jack is used instead of a ramp, jack stands should be used because the crane itself is not safe. Fig. 23 shows a view of the drain plug and oil filter.

Fig. 24 illustrates an opening in the crankcase through which the oil is drained and the filter joint is cleaned. The unscrewed old filter, shown in Fig. 25, is full of old oil. In order to be treated as nonhazardous waste, it must be punctured and oil must be drain from it. Fig. 25 also shows a new aluminum drain plug gasket that will be put under the drain plug screw. Washer dimensions are 14,05 $\times 20,4$ $\mathrm{mm}$, thickness $2 \mathrm{~mm}$, but available washers DIN 7603 Type A can be used.

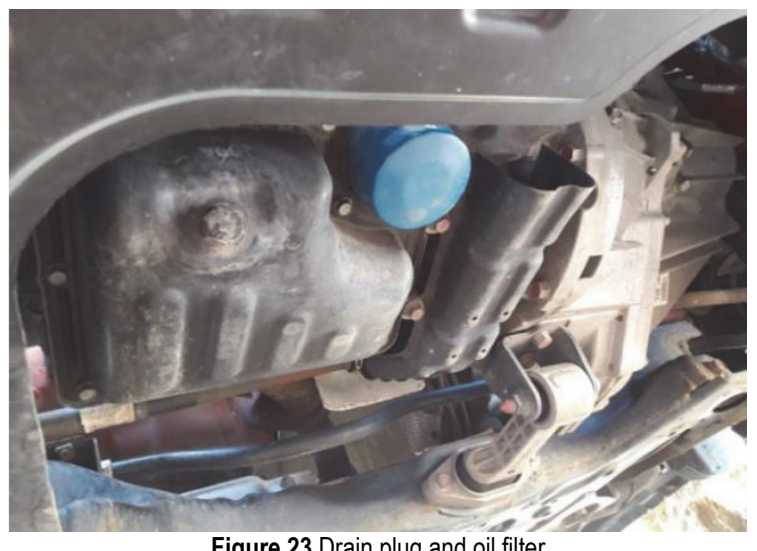

Figure 23 Drain plug and oil filter

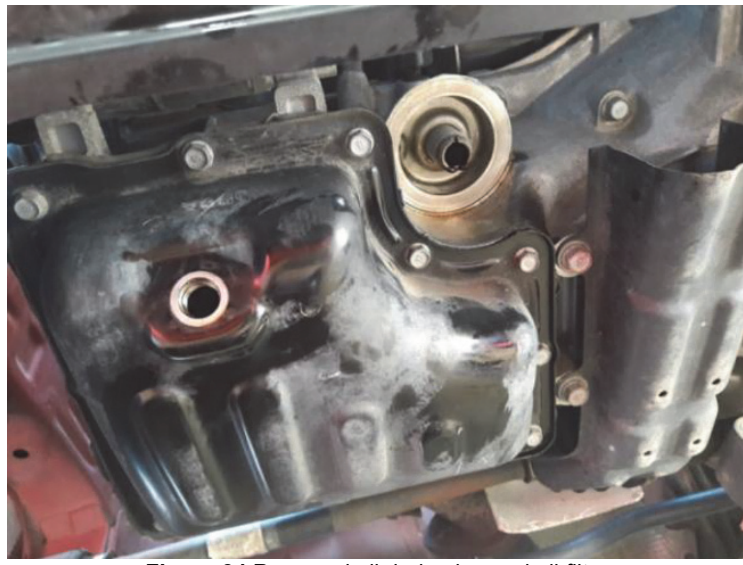

Figure 24 Removed oil drain plug and oil filter

In practice, the oil filter is tightened manually as far as it goes, and the drain plug snags with a wrench. In our case, a torque wrench was used for both operations pursuant to the manufacturer's instructions. Fig. 26 depicts the engine and oil cap marked with a yellow circle through which 3 liters of new oil were poured.

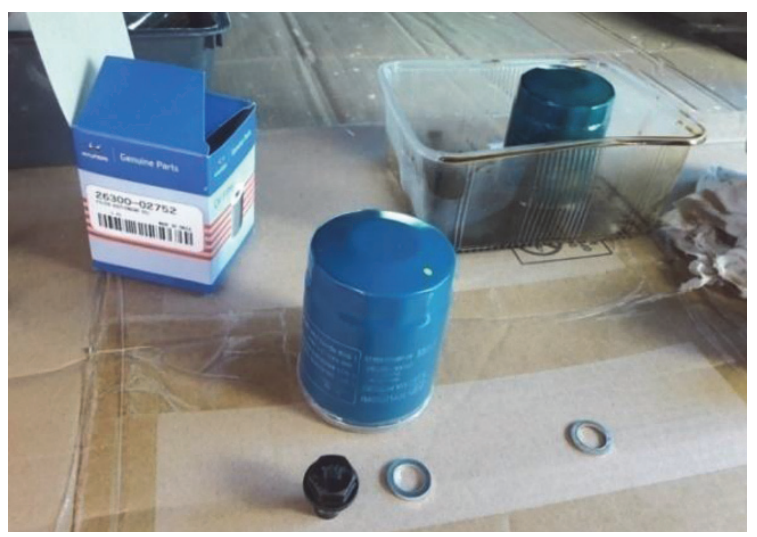

Figure $25 \mathrm{New}$ oil filter and drain plug gasket

Upon filing the engine with new oil, it is necessary to start the car and check for oil leaks as shown in Fig. 27. After checking, the car is lowered and topped up with oil 
until the control bar shows a level within the minimum and maximum range.

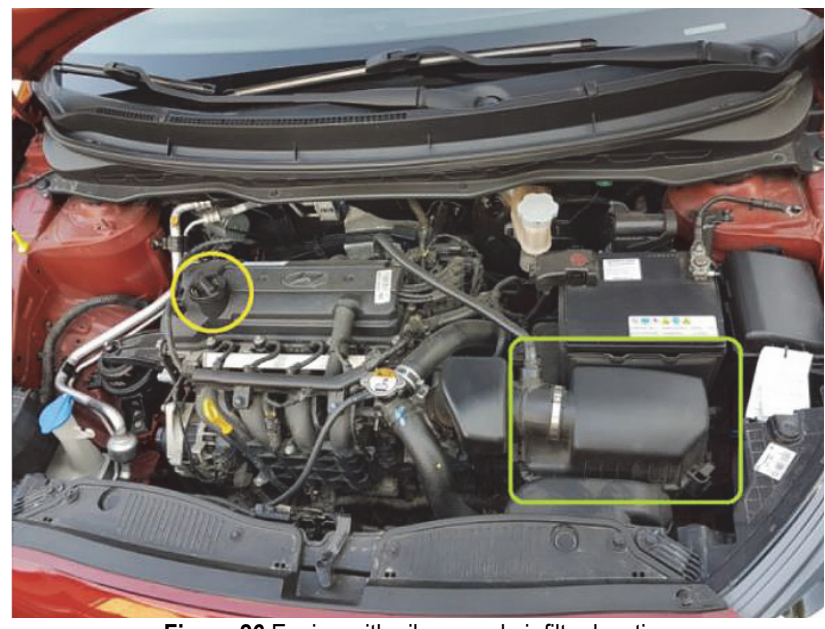

Figure 26 Engine with oil cap and air filter location
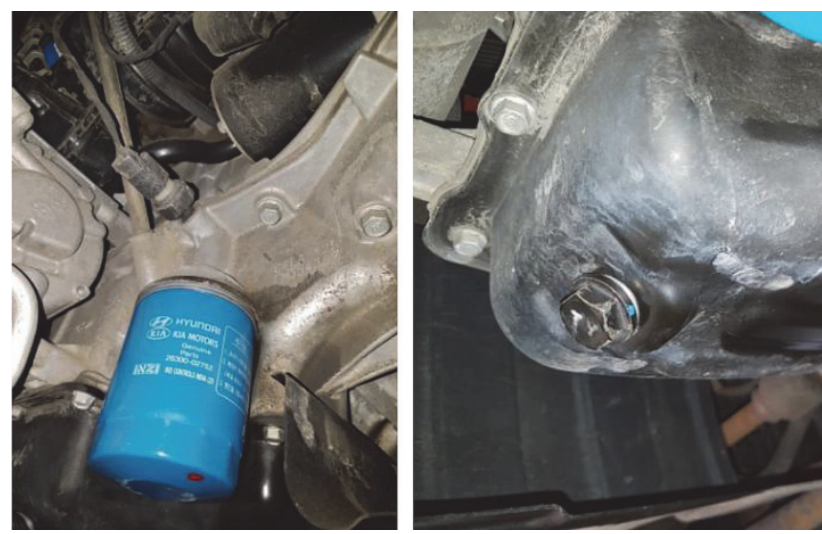

Figure 27 Looking for oil leaks after filing the engine with new oil

The next step is to check the air filter with a change interval of $30000 \mathrm{~km}$ or every second oil change. If the filter use duration is unknown, it is recommended to make a replacement. Fig. 28 shows old and new filters. Based on the color, it cannot be determined that the old filter has served its purpose, but the view towards the light source shows the opacity resulting from the accumulated dust.

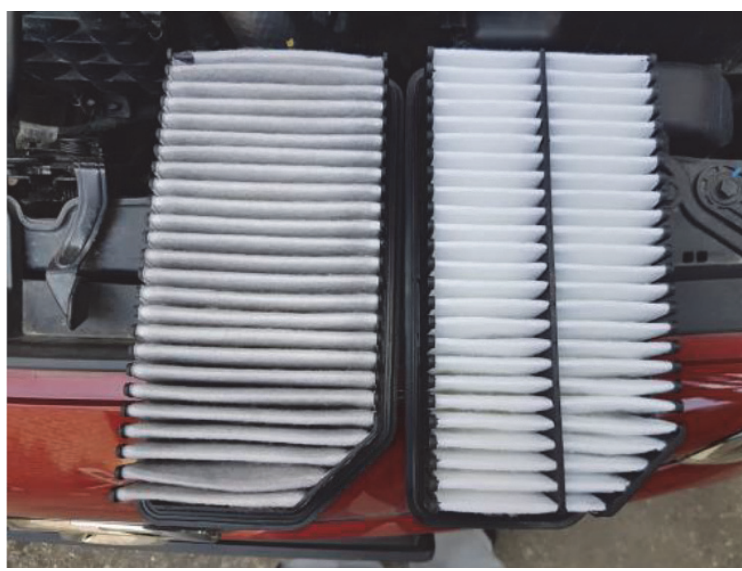

Figure 28 Old (left) and new (right) air filter

Fig. 29 shows the new and old climate filter, which clearly points to a color change most often caused by a combination of dust and the development of microorganisms.

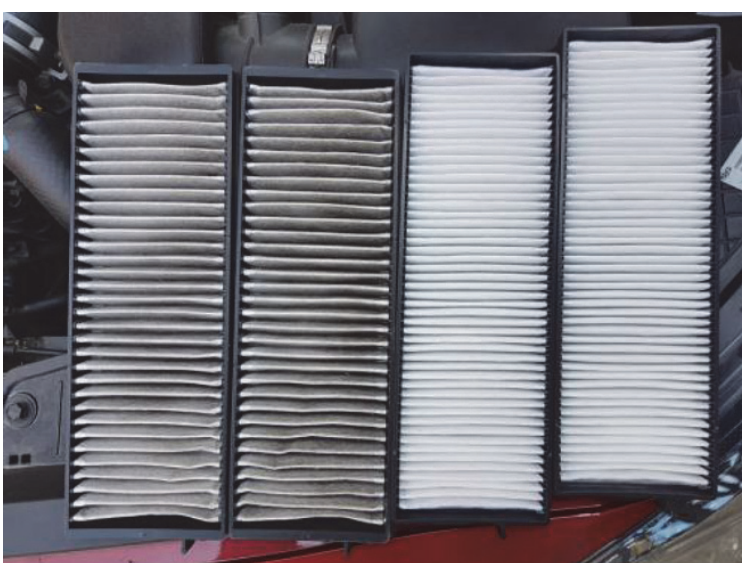

Figure 29 Passenger compartment (air conditioning) filter used left and new right

Basic vehicle service carried out by the everyday user with a certain level of technical education is so called interim service. Changing the engine oil can be done more easily by using a filler pump through the dipstick pipe to check the oil level. Pumps are most often hand-held vacuum pumps. Recently, you can find electric pumps in the price range of $€ 9$ with power of $60 \mathrm{~W}$ that draws current of $5 \mathrm{~A}$ in the nominal range. The pump's main power source car battery, in this case, should be charged; therefore, it is advisable to check it before starting the procedure. Fig. 30 shows the measurement of the battery voltage in the unloaded state and, according to [41], it can be concluded that the state of charge is $100 \%$.

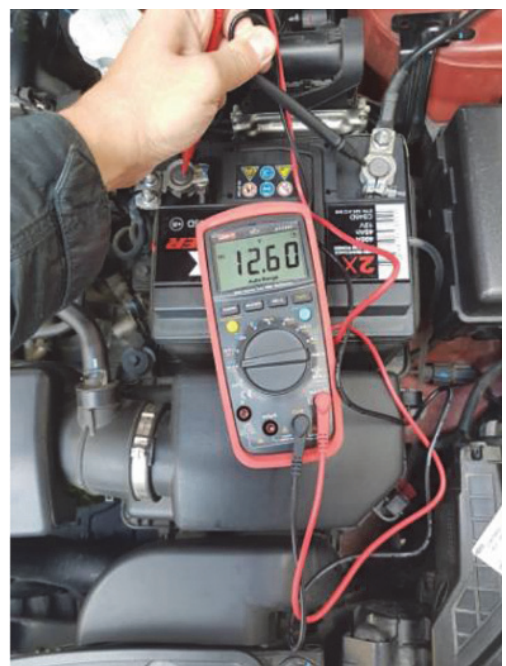

Figure 30 Checking the battery charge status

The engine is warmed up in order to reduce the oil viscosity and consequently the pump load, i.e. the battery. Temperature information can be obtained via the OBD interface using the ISO 15765-4 CAN (29 bit ID, 250 kbaud) protocol, but the temperature check was performed faster and easier using infrared thermography. Fig. 31 shows a thermographic record of the coolant temperature monitoring in the heating process.

The reason for this is the high rubber emissivity of 0,97 ; which reduces the measurement error and large heat capacity of the coolant thus allowing the system thermal inertia. The motor is heated to $50{ }^{\circ} \mathrm{C}$, if possible and less, because at temperatures higher than $60{ }^{\circ} \mathrm{C}$, the plastic connecting the pump pipes is deformed. The heating state 
is best checked tactilely, i.e. by touching the oil pan area. When the temperature becomes unbearable for continuous contact, it is necessary to turn off the car.

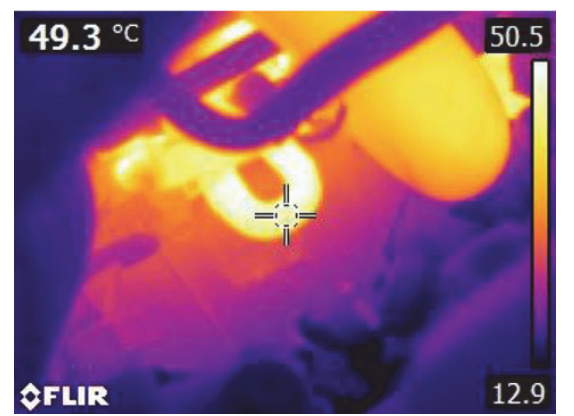

Figure 31 Measurement of engine temperature at the coolant hose

The suction hose of the pump should be placed in the pipe of the control rod, and the outlet hose in the vessel that will accept the oil. The electrical contacts of the pump are connected to the car battery.

Switching on the pump starts the oil pumping process. In this case, for 3 liters, it took 9 minutes with one interruption to adjust the suction hose, i.e. to put it in the lowest point of the oil pan. Fig. 32 and Fig. 33 show the principal temperatures at the time of pumping; outside temperature was approx. $15^{\circ} \mathrm{C}$, oil temperature approx. 34 ${ }^{\circ} \mathrm{C}$ and pump housing $41^{\circ} \mathrm{C}$.
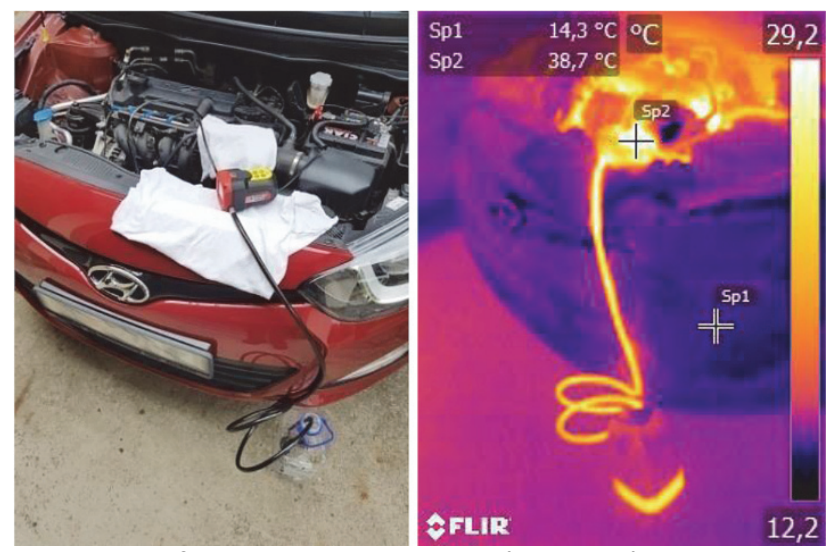

Figure 32 Oil sputtering in the visual and infrared part of the spectrum

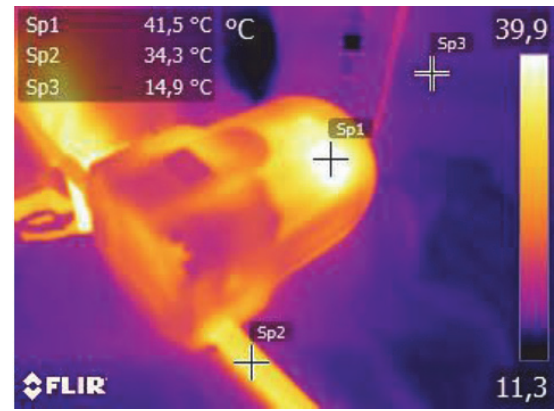

Figure $33 \mathrm{IR}$ thermographic inspection of an oil pump in operation

After completing the pumping process, the suction hose can be immersed in $2 \mathrm{dl}$ of diesel fuel to flush the pump. The oil change was properly carried out owing to the fact that the oil filter was not replaced. The built-in filter is designed for replacement intervals of $30000 \mathrm{~km}$ and is used as well as $7200 \mathrm{~km}$ oil. A premature oil change is not necessarily a proactive approach to maintenance because, in accordance with [13], for passenger vehicles in most cases, lubrication oil was discarded well before it reached its maximum usable life. Frequent lubrication oil change without the proper transition time will cause unnecessary engine or machinery damage. The lubrication oil change process requires time for the oil to completely soak the filters and diffuse into the entire lubricant circulation systems. The oil change is made as an optimal solution for the overall maintenance of the vehicle (Fig. 34).

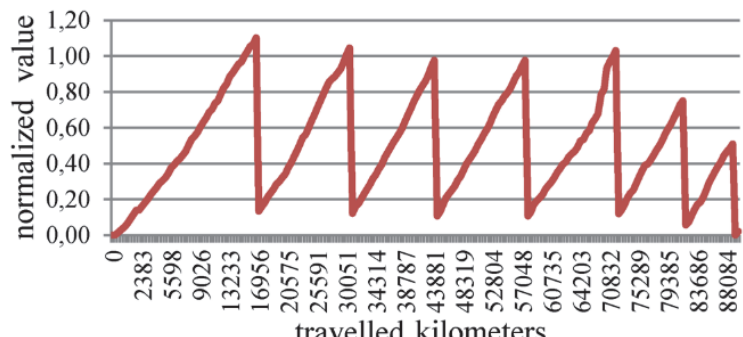

Figure 34 Normalized display of oil condition with respect to the number of kilometers traveled between services

The abscissa in Fig. 34 shows the number of travelled kilometers with an increase increment in the form of an interval between individual refueling of the fuel tank. The ordinate shows the normalized amount of oil contamination based on the prescribed oil change interval of $15000 \mathrm{~km}$ [20].

As indicated in Fig. 34, 7 services have been made since the beginning of the vehicle operation. The oil at the very beginning was clean and the associated value of contamination is 0 . The first service was made at $16509 \mathrm{~km}$ and the service interval was exceeded by $10 \%$, by which the oil property was further impaired. When changing a total of 3,6 liters of oil, 3,2 liters are replaced, which means that $11 \%$ of the old oil remains in the engine, thus impairing the properties of the mixture with the new oil. The sixth service was made at $10330 \mathrm{~km}$, which improved the initial mixture condition provided for the seventh service interval to 0,06 compared to the average of 0,12 . In the seventh service, $83 \%$ of oil was replaced and the normalized value is 0 , which is not realistic and is a consequence of the application of a simplified linear model with unadjusted contamination weights at the time of replacement that does not correspond to the real situation due to a linear approach to oil degradation. The modeling presented in [42] led to the conclusion that modeling should be approached statistically taking into account the real behavior of the oil during exploitation. It is also the subject of future research, [29, 43]. Premature oil change, shown in the paper, was made in order to improve the condition of the engine oil mixture but also to plan the next service at a time when outdoor temperatures are suitable for work, i.e. to avoid service in January at the lowest temperatures in the year.

\section{CONCLUSION}

Vehicle servicing must be carried out regularly in accordance with the manufacturer's instructions. Used spare parts and lubricants should be selected in accordance with the quality striving for the techno-economic optimum. If the vehicle operating dynamics is slowed down, the service interval may be extended, but not significantly as 
there is a possibility of contamination and degradation of lubricants and fluids during the period of inactivity. Filters used for air filtration should be selected based on the quality of the filtration material. During the inspection, it is not advisable to clean an air filter using compressed air as mechanical damage may occur. The condition of the air filter is best controlled by measuring the mass accumulated in the filtration material. The oil filters must be replaced during each oil change as well as the washer, which deforms by tightening the screw.

Basic vehicle service is presented as a practical example in the work that can be carried out by the everyday user with a certain level of technical education, which independently and periodically, monitors the car condition. A proactive approach in the form of changing the oil in the car too often is neither good for environmental nor for technical reasons because it can lead to premature tear and wear of the engine through unprofessional procedures.

The paper analyzes the process of maintaining a pandemic emergency. When the situation allows, it is advisable to take the vehicle to an authorized service center, which will carry out complete diagnostics and give maintenance recommendations in order to extend its service life.

\section{REFERENCES}

[1] Sniderman, D. (Contributing Editor) (2017). The chemistry and function of lubricant additives. Tribology \& Lubrication Technology. www.stle.org

[2] Pinkus, O. \& Wilcock, F. D. (1978). The Role of Tribology in Energy Conservation. Lubrication Engineering, 34(11), 599-610. https://doi.org/10.1016/0301-679X(78)90083-X

[3] Wichtl, R., Schneider, M., Grabner, P., \& Eichlseder, H. (2016). Experimental and Simulative Friction Analysis of a Fired Passenger Car Diesel Engine with Focus on the Cranktrain. SAE International Journal of Engines, 9(4), 2227-2241. https://doi.org/10.4271/2016-01-2348

[4] Okpokwasili, G. C. \& Okorie, B. B. (1990). Influence of Physico-chemical Stress on Biodegradability of Car Engine Lubricating Oil.International Biodeterioration, 27, 255-264. https://doi.org/10.1016/0265-3036(91)90054-U

[5] Okpokwasili, G. C. \& Okorie, B. B. (1988). Biodeterioration potentials of microorganisms isolated from car engine lubricating oil. TRIBOLOGY international, Butterworth \& Co (Publishers) Ltd. https://doi.org/10.1016/0301-679X(88)90020-5

[6] Bonvoisin, J., Galla, J., \& Prendeville, S. (2017). Design Principles for Do-It-Yourself Production. Sustainable Design and Manufacturing 2017, Springer International Publishing AG: 2017, 77-86. https://doi.org/10.1007/978-3-319-57078-5_8

[7] Van Donkelaar, P. (1990). Environmental effects of crankcase- and mixed-lubrication.Science of the Total Environment, 92,165-179. https://doi.org/10.1016/0048-9697(90)90328-R

[8] California Department of Resources Recycling and Recovery, Used Oil and Filter Facts.Retrieved 30 April 2020 https:// www.calrecycle.ca.gov/ usedoil/ facts

[9] Schoner, H. P. (2004). Automotive mechatronic.Control Engineering Practice, 12, 1343-1351. https://doi.org/10.1016/j.conengprac.2003.10.004

[10] Srivastava, S. P. (2014). Developments in Lubricant Technology. First Edition, John Wiley \& Sons, Inc. https://doi.org/10.1002/9781118907948

[11] Wadi, V. T., Özmen, Ö., \& Karamış, M. B. (2020). Experimental analysis and modeling of viscosity and thermal conductivity of GNPs/SA 5W40 nanolubrican.Industrial Lubrication and Tribology, (forthcoming) https://doi.org/10.1108/LLT-03-2020-0088

[12] Bommareddi, A. (2009). An engine oil life algorithm, A Thesis in Mechanical Engineering. The Pennsylvania State University, The Graduate School Department of Mechanical and Nuclear Engineering.

[13] Zhu, J., He, D., \& Bechhoefer, E. (2012). A survey of lubrication oil condition monitoring, diagnostics and prognostics techniques and systems. Journal of Chemical Science and Technology, 2(3), 100-115.

[14] Fox, M. F., Picken, J. D., \& Pawlak, Z. (1990). The effect of water on the acid-base properties of new and used IC engine lubricating oils. Tribology International, 23(3), 183-187, https://doi.org/10.1016/0301-679X(90)90015-H

[15] Espínola, L. H. (2018). Analysis of cylinder liners lubrication systems in modern slow speed marine engines. Final Degree Project, Barcelona Nautical Faculty Polytechnic University of Catalonia, Department of Nautical Science and Engineering, Barcelona.

[16] Tormos, B., Ramirez, L., Miró, G., \& Pérez, T. (2017). Real World Fleet Test to Determine the Impact of Low Viscosity Engine Oils from Heavy-Duty CNG and Diesel Buses. Part I: Fuel Consumption SAE Technical Paper 2017-01-2353, https://doi.org/10.4271/2017-01-2353

[17] Wolak, A., Zając, G., Fijorek, K., Janocha, P., \& Matwijczuk, A., (2020). Experimental Investigation of the Viscosity Parameters Ranges. Case Study of Engine Oils in the Selected Viscosity Grade. Energies 2020, 13, 3152. https://doi.org/10.3390/en13123152

[18] Sejkorová, M., Hurtová1, I., Glos, J., \& Pokorný, J. (2017). Definition Of A Motor Oil Change Interval For High-Volume Diesel Engines Based On Its Current Characteristics Assessment, Acta Universitatis Agriculturae Et Silviculturae Mendelianae Brunensis, 65(2), 481-490 https://doi.org/10.11118/actaun201765020481

[19] Durst, M., Klein, G. M., \& Moser, N. (2002). Automotive Filtration Basics and examples of air, oil and fuel filtration. Verlag moderne industrie. Augsburg, Germany

[20] Hyundai, Warranty service booklet i20, Hyundai Auto Zagreb, 03/2014

[21] Wei, L., Haitao, D., Song, C., Dan, J., Yongliang, J., Xuzheng, Q., Jianfang, L., \& Jian, L. (2019). Discussion on the influence of driving parameters of civilian cars on motor oil degradation.Proceedings of the Institution of Mechanical Engineers, Part J: Journal of Engineering Tribology, 233(2), 281-288. https://doi.org/10.1177/1350650118776567

[22] Bates, T. W. (1995). Effect of automotive technology and environmental factors on lubricant requirements. Lubricants and Lubrication (Editors D. Dowson et al.), Elsevier Science B.V. https://doi.org/10.1016/S0167-8922(08)70611-4

[23] Kaleli, H. \&Yavasliol, I. (1997). Oil ageing - Drain period in a petrol engine.Industrial lubrication and tribology, 49(3), 120-126. https://doi.org/10.1108/00368799710165747

[24] Macián, V., Tormos, B., Bastidas, S., \& Pérez, T. (2020). Improved fleet operation and maintenance through the use of low viscosity engine oils:fuel economy and oil performance. Eksploatacja i Niezawodnosc-Maintenance and Reliability 2020, 22(2), 201-211. https://doi.org/10.17531/ein.2020.2.3

[25] Wei, L., Haitao, D., Yongliang, J., Dan, J., Song, C., Jianfang, L., \& Jian, L. (2019). Oil change interval evaluation of civilian cars in urban traffic condition. Proceedings of the Institution of Mechanical Engineers, Part $J$ : Journal of Engineering Tribology, 233(6), 956-964. https://doi.org/10.1177/1350650118809772

[26] Ishibashi, A., Sunagawa, Y., Sonoda, K., \& Ezoe, S. (2010). Performance of Used Engine Oil as Gear-Cutting Oil. Tribology Transactions, 47(2), 272-279. https://doi.org/10.1080/05698190490439292 
[27] Choong, C. G., Saw, C., L., \& Chiang, Y. Y. (2018). Design and Analysis of an Automotive Oil Filter Gripper Socket Special Tool. Springer International Publishing AG. https://doi.org/10.1007/978-3-319-72697-7_6

[28] Feng, J., Zhang, J., Zhang, H., \& Yang, X. (2012). Based on a linear regression method to study the fiber diameter of car engine oil filter materials.Advanced Materials Research, 507, 16-20 Online: 2012-04-25, Trans Tech Publications, Switzerland. https://doi.org/10.4028/www.scientific.net/AMR.507.16

[29] Emad, A., Khorshid, A. M., \& Nawwar, A. (1991). Review of the effect of sand dust and filtration on automobile engine wear, Wear, 141, 349-371. https://doi.org/10.1016/0043-1648(91)90279-4

[30] Dziubak, T. \& Dziubak, S. D. (2020). Experimental Study of Filtration Materials Used in the Car Air Intake, Materials 13, 3498. https://doi.org/10.3390/ma13163498

[31] Dziubak, T. (2019). Properties of material with nanofiber layer used for filtering the inlet air of internal combustion engines. Combustion Engines, 177(2), 66-75. https://doi.org/10.19206/CE-2019-212

[32] Ahmadipour, F., Esmaeili Sari, A., \& Bahramifar, N. (2019). Characterization, concentration and risk assessment of airborne particles using car engine air filter (case study: Tehran metropolis). Environ Geochem Health, 41, 26492663. https://doi.org/10.1007/s10653-019-00319-1

[33] Min, T., Jian, H., Yun, L., \& David, Y. H. P. (2017). Pressure drop, penetration and quality factor of filter paper containing nanofibers. Textile Research Journal, 87(4), 498-508. https://doi.org/10.1177/0040517516631318

[34] Trautmann, P., Durst, M., Pelz, A. \& Moser, N. (2005). High performance nanofibre coated filter media for engine intake air filtration, 6, 53-56. AFS 2005 Conference and Expo.

[35] Heikkilä, P., Auli, S., Minna, P., Ali, H., \& Aimo, T. (2007). Electrospun PA-66 Coating on Textile Surfaces. Textile Research Journal, 77(11), 864-870. https://doi.org/10.1177/0040517507078241

[36] Grafe, T. \& Graham, K. (2003). Polymeric Nanofibers and Nanofiber Webs: A New Class of Nonwovens. International Nonwovens Journal, 12(1). https://doi.org/10.1177/1558925003os-1200113

[37] Durst, M., Klein, G. M., Moser, N., \& Trautmann, P. (2007) Filtration und Separation in der Automobiltechnik. Chemie Ingenieur Technik, 9(11), Filtration, 1845. https://doi.org/10.1002/cite.200700153

[38] Alexandropoulou, I. G., Konstantinidis, T. G., Parasidis, T. A., Nikolaidis, C., Panopoulou,M., \& Constantinidis, T. C. (2013). First report of Legionella pneumophila in car cabin air filters. Are these a potential exposure pathway for professional drivers?.Scandinavian Journal of Infectious Diseases, 45, 948-952. https://doi.org/10.3109/00365548.2013.840917

[39] Nick, M., Sam, B., Kent, J., \& Heejung, J. (2019). Development of a Standard Testing Method for Vehicle Cabin Air Quality Index.SAE Int. J. Commer. Veh., 12(2), 151-161. https://doi.org/10.4271/02-12-02-0012

[40] i20 Kappa (к) Engine, Service information, Hyundai Motor Europe $\mathrm{GmbH}, 2008$.

[41] Balukčić, L., Glavaš, H., \& Vidaković, D. (2020). Detection of Parasitic Consumption of Personal Car Electric System.6. Konferencija "ODRŽAVANJE 2020" Zenica, B\&H, 2020.

[42] Wolak, A. (2019). Statistical Analysis of HTHS Viscosity Rating of Present-Day Engine Oils.Journal Tribology Transactions, 62(1), 34-41. https://doi.org/10.1080/10402004.2018.1468518

[43] Wang, S. S. (2001). Road tests of oil condition sensor and sensing technique.Sensors and Actuators B, 73(2-3), 106111. https://doi.org/10.1016/S0925-4005(00)00660-2

\section{Contact information}

Hrvoje GLAVAŠ, Associate Professor

Faculty of Electrical Engineering, Computer Science and Information

Technology Osijek,

Kneza Trpimira 2b, 31000 Osijek, Croatia

E-mail: hrvoje.glavas@ferit.hr

Mirko KARAKAŠIć, Associate Professor

(Corresponding author)

University in Slavonski Brod, Mechanical Engineering Faculty in Slavonski Brod,

Trg Ivane Brlić Mažuranić 2, 35000 Slavonski Brod, Croatia

E-mail: mkarakasic@unisb.hr

Milan KLJAJIN, Full Professor with Tenure

University North, University Center Varaždin

Jurja Križanića 31b, 42000 Varaždin, Croatia

E-mail: mkljajin@unin.hr

Eleonora DESNICA, Associate Professor

University of Novi Sad, Technical Faculty "Mihajlo Pupin",

Đure Đakovića bb, 23000 Zrenjanin, Republic of Serbia

E-mail: desnica@tfzr.uns.ac.rs 